\title{
STUDI HYGIENE SANITASI DAN KUALITAS MIKROBIOLOGI (Salmonella sp) PADA DAGING
}

\author{
Minati Indriani Nur Imaniah"1), Asep Tata Gunawan²) \\ Poltekkes Kemenkes Semarang, Poltekkes Kemenkes Semarang
}

\begin{abstract}
Abstrak
Makanan dan minuman seringkali menjadi penyebab timbulnya berbagai macam penyakit. Makanan atau minuman yang tercemar akan menjadi media yang baik bagi pertumbuhan mikroorganisme (bakteri). Bakteri yang sering dijumpai pada makanan dan minuman tercemar salah satunya adalah Salmonella sp. Tujuan penelitian ini adalah mengetahui hygiene sanitasi dan kualitas mikrobiologi (Salmonella sp) pada daging sapi di Pasar Wage Kecamatan Purwokerto Timur Kabupaten Banyumas. Metode penelitian yang digunakan adalah metode deskriptif yang menggambarkan hygiene sanitasi dan kualitas mikrobiologi (Salmonella $s p$ ) pada daging sapi. Hasil penelitian diperoleh prinsip hygiene sanitasi pada 6 pedagang mulai dari bahan baku daging sapi untuk 4 sampel memenuhi syarat dan 2 sampel tidak memenuhi syarat, pemotongan daging sapi dikategorikan tidak memenuhi syarat, penyajian daging sapi dikategorikan tidak memenuhi syarat, personal hygiene dikategorikan tidak memenuhi syarat dan perilaku penjamah dikategorikan memenuhi syarat. Sedangkan sanitasi tempat penjualan dari peralatan dikategorikan memenuhi syarat dan tempat penjualan dikategorikan tidak memenuhi syarat. Berdasarkan pemeriksaan sampel dari 6 pedagang di laboratorium, 6 sampel daging sapi yaitu 2 sampel positif Salmonella $s p$ dan 4 sampel negatif Salmonella sp. Kesimpulan bahwa hygiene sanitasi daging sapi di 6 pedagang masih ada yang belum memenuhi syarat, sanitasi tempat penjualan daging sapi di 6 pedagang masih ada yang belum memenuhi syarat serta dalam 6 sampel daging sapi ada 2 sampel positif Salmonella $s p$ dan 4 sampel lainnya negatif Salmonella sp.
\end{abstract}

Kata kunci: Daging sapi; Salmonella sp; Kesehatan Lingkungan

\begin{abstract}
Food and drink are often the cause of various diseases. Contaminated food or drink will be a good medium for the growth of microorganisms (bacteria). Salmonella sp is one of the most common bacteria in contaminated food and drink. The purpose of this research is to know hygiene sanitation and quality of microbiology (Salmonella sp) on beef in Pasar Wage, Purwokerto Timur District, Banyumas Regency. The research method used is descriptive method describing sanitation hygiene and quality of microbiology (Salmonella sp) in beef. The results of the research, the principle of hygiene sanitation on 6 traders was obtained. A total of 4 raw materials of beef are found to be eligible, while 2 samples are not eligible. This can be known from the results of laboratory examination, that 4 samples are negative to Salmonella sp, while 2 samples are positive to Salmonella sp. Furthermore, the cutting and serving of beef, personal hygiene, and also sanitation of the place for trading are categorized as ineligible, whereas the behaviour of the handlers and sanitation of equipment for trading are categorized as eligible.Conclusions that, there are still ineligible hygiene sanitation of beef and sanitation of the place for trading on 6 traders, moreover in 6 samples of beef there are 2 samples which positive to Salmonella sp and 4 other samples are negative to Salmonella sp.
\end{abstract}

Keywords: Beef; Salmonella sp; Environmental Health

\footnotetext{
1) E-mail: indrianinurimaniah@ @mail.com

${ }^{2)}$ E-mail: aseptatagunawan@yahoo.co.id
} 


\section{Pendahuluan}

Makanan merupakan kebutuhan pokok seharihari yang penting untuk kelangsungan hidup manusia. Aktivitas manusia mengalami hambatan jika makanan yang dikonsumsi tidak cukup dalam jumlah dan mutunya. Makanan dapat diperoleh dari hewan (hewani) dengan tujuan sebagai pemberi zat gizi bagi tubuh yang dibutuhkan untuk mempertahankan hidup (Leni Herliani Afrianti, 2010, h.31).

Makanan dalam bentuk apapun seyogyanya memperhatikan kaidah-kaidah kebersihan (hygiene) dan sanitasi serta persyaratan kesehatan agar tidak menimbulkan gangguan kesehatan masyarakat. Kondisi bahan makanan yang sehat dapat membantu peningkatan kesejahteraan masyarakat. Kemampuan masyarakat dalam memenuhi kebutuhan gizi seimbang dipengaruhi oleh daya beli, pengetahuan dan penyediaan pangan mencakup kualitas dan kuantitas bahan pangan untuk dikonsumsi sesuai standart kebutuhan energi bagi individu agar mampu menjalankan aktifitas sehari-hari (Dinkes Prop Sumut, 2006).

Masyarakat Indonesia sudah semakin kritis terhadap masalah keamanan produk pangan yang dikonsumsi. Makanan dan minuman seringkali menjadi penyebab timbulnya berbagai macam penyakit. Makanan atau minuman yang tercemar akan menjadi media yang baik bagi pertumbuhan mikroorganisme (bakteri). Bakteri yang sering dijumpai pada makanan tercemar salah satunya adalah Salmonella sp. Pada umumnya infeksi Salmonella $s p$ menyebabkan penyakit salmonellosis (penyebab: Salmonella choleraesuis dan Salmonella enteriditis) dengan ditandai gejala mual, muntah sakit kepala, sakit perut, diare hebat dan penyakit demam typhoid (penyebab: Salmonella typhi) yang memiliki gejala demam yang berkelanjutan, disertai sakit kepala, tidak nafsu makan, dengan bercakbercak kemerahan ditubuh, sedikit batuk, susah buang air besar, gejala panas berlanjut sampai dua minggu (bila tidak diobati), dinding usus mengalami perlukaan dan menjadi sangat tipis, sehingga terjadi jebolnya dinding usus (Dirjen PP \& PL Depkes RI 2010).

Salah satu akibat penyediaan makanan yang tidak memenuhi syarat kesehatan adalah keracunan makanan. Kasus keracunan makanan termasuk masalah serius tidak memilih orang, tempat dan waktu dapat menyerang siapa saja, dimana saja, kapan saja, mulai dari anak-anak hingga lansia. Kasus keracunan makanan terjadi di Kabupaten Nunukan ada 70 korban terdiri dari dewasa sebanyak 28 orang laki laki dan perempuan 31 orang serta anak laki-laki sebanyak 6 orang dan perempuan 5 orang, yang telah memeriksakan diri di Puskesmas Nunukan. Kasus keracunan makanan tersebut terjadi diduga setelah menyantap makanan dari daging sapi (kaltim.tribunnews.com diakses pada 5 Juni 2018 05.30 WIB).
Bakteri Salmonella ini bisa dijumpai dalam berbagai jenis makanan. Bukan hanya yang telah diolah tetapi juga bahan makanan mentah. Salmonella ini sering sekali dijumpai pada daging mentah, sayur mentah dan buah yang masih dalam keadaan segar. Selain itu, berdasarkan penjelasan para ahli, bakteri salmonella ini ternyata juga bisa menjangkiti binatang peliharaan. Oleh karena itu, higienitas semua komponen mulai dari makanan hingga lingkungan sekitar perlu diperketat agar terhindar dari bakteri pathogen ini (Nurul Amaliyah, 2017, h. 68)

Daging sapi merupakan produk bahan makanan mentah yang mempunyai potensi bahaya mikrobiologis (Salmonella sp) disebabkan karena produk daging sapi memiliki kandungan nutrisi, $\mathrm{pH}$, dan kadar air yang cukup tinggi sehingga sangat baik untuk pertumbuhan mikroba dan mengakibatkan produk mudah rusak. Produk yang terkontaminasi oleh mikroba, mengalami penurunan mutu dan berisiko terhadap kesehatan manusia, bahkan dapat menyebabkan kematian. Oleh karena itu daging sapi yang diedarkan di pasar harus memenuhi aspek kesehatan sehingga aman untuk dikonsumsi (Emil Salim, 2013, h. 77).

Pasar Wage merupakan salah satu pasar tradisional milik pemerintah daerah Kabupaten Banyumas yang letaknya di tengah kota tepatnya di Kecamatan Purwokerto Timur Kabupaten Banyumas. Pasar Wage sebelumnya berstatus Pasar Induk, kini statusnya berubah menjadi Pasar Kota. Jenis Pasar Wage menurut waktu termasuk pasar harian yaitu pasar ini tetap hidup dan ada aktifitas selama 24 jam setiap harinya menjual berbagai jenis barang kebutuhan konsumsi, kebutuhan jasa, kebutuhan bahan-bahan mentah, dan kebutuhan produksi.

Hasil kegiatan survey pendahuluan di Pasar Wage setiap harinya ramai pembeli guna membeli kebutuhan sehari-hari salah satunya bahan-bahan mentah seperti daging sapi. Pembeli yang terdapat di Pasar Wage tidak hanya orang sekitar wilayah tersebut tetapi dari berbagai wilayah lain. Banyak pedagang daging sapi masih belum memperhatikan kebersihan individu pedagang satu yang tidak memakai celemek, tidak memakai sarung tangan, tidak mencuci tangan setiap akan menangan makanan, kebersihan tempat penjualan serta penyajian daging sapi tidak diberi penutup, sehingga memungkinkan lalat hinggap pada daging sapi.

Berdasarkan latar belakang diatas, penulis tertarik untuk melakukan penelitian dengan mengambil judul "Studi Hygiene Sanitasi dan Kualitas Mikrobiologi (Salmonella sp) Pada Daging".

\section{Bahan dan Metode}

Penelitian ini termasuk jenis penelitian deskriptif yaitu memberi gambaran tentang hygiene sanitasi dan kualitas mikrobiologi (Salmonella sp) pada 
daging sapi di Pasar Wage Kecamatan Purwokerto Timur Kabupaten Banyumas.

Waktu dalam penelitian ini dibagi menjadi 3 tahap, tahap persiapan Desember-Januari 2018, tahap pelaksanaan Januari-April 2018 dan tahap penyelesaian April-Mei 2018.

Cara Pengumpulan Data :

a. Observasi dilakukan dengan cara pengamatan dan pencatatan langsung secara nyata di lapangan mengenai bahan baku, pemotongan, penyajian, personal hygiene, perilaku penjamah, peralatan penjualan dan tempat penjualan pedagang daging sapi di Pasar Wage Kecamatan Purwokerto Timur Kabupaten Banyumas.

b. Pengambilan sampel daging sapi di Pasar Wage Kecamatan Purwokerto Timur Kabupaten Banyumas.

c. Pemeriksaan laboratorium dilakukan untuk pemeriksaan Salmonella $s p$ pada daging sapi dengan metode kualitatif yaitu metode sebaran, metode tusuk dan metode goresan.

Instrument pengumpul data dalam penelitian ini digunakan checklist untuk observasi, alat bahan pengambilam sampel dan pemeriksaan laboratorium untuk pemeriksaan salmonella pada sampel daging sapi.

Analisis yang digunakan dalam penelitian adalah deskriptif dengan menguraikan hasil pengamatan yang disajikan dalam bentuk tabel lalu membandingkan hasil di lapangan dengan standar ketentuan yang berlaku.

\section{Hasil dan Pembahasan}

\section{A. Data Umum}

\section{Kondisi Geografis}

Pasar Wage merupakan salah satu pasar tradisional milik pemerintah daerah Kabupaten Banyumas yang letaknya di tengah kota tepatnya di Kecamatan Purwokerto Timur Kabupaten Banyumas. Pasar Wage memiliki luas area yaitu $10.305,44 \mathrm{~m}^{2}$. Pasar Wage memiliki batasbatas sebagai berikut :
a. Batas Timur
: Jl. MT. Haryono
b. Batas Barat
: Jl. Brigjen Katamso
c. Batas Utara
: Jl. Vihara
d. Batas Selatan
: Jl. Jend. Soedirman

\section{Kondisi Pedagang}

Pasar Wage adalah suatu tempat transaksi jual beli yang banyak diminati masyarakat khususnya wilayah Kecamatan Purwokerto Timur dan sekitarnya. Pasar ini buka setiap hari dan ramai dikunjungi masyarakat karena letaknya yang strategis berada di tengah kota, mudah dijangkau dengan transportasi umum. Jumlah pedagang yang terdapat di Pasar Wage sejumlah 1.837 pedagang yang menjual berbagai kebutuhan sehari-hari diantaranya sayur-sayuran, daging, bahan makanan, buah-buahan, maupun kebutuhan sandang.

3. Fasilitas Pasar

Fasilitas yang dimiliki Pasar Wage adalah :
a. Kios
: 206 unit
b. Los
: 2.449 unit
c. WC
$: 6$ unit
d. Kantor Administrasi : 2 unit
e. Pos Keamanan : : 4 unit
f. Masjid : 1 unit
g. Parkiran
: 11 unit

4. Sarana dan Prasarana Pasar Wage

Pasar Wage memiliki keamanan 24 jam dan memiliki bangunan permanen untuk berjaga seperti pos keamanan. Kegiatan keamanan pasar dilakukan secara bergantian atau shift. Sarana kebersihan yang terdapat di Pasar Wage meliputi ketersediannya tong sampah, gerobak sampah, truck sampah dan Tempat Penampungan Sampah yang terletak di satu lokasi.

5. Data Lokasi Pedagang Daging Sapi di Pasar Wage

Data lokasi pedagang daging sapi di Pasar Wage dapat dilihat pada tabel berikut : Tabel 1. Data Lokasi Pedagang Daging Sapi di Pasar Wage

\begin{tabular}{|c|c|c|c|}
\hline No. & $\begin{array}{c}\text { Nama } \\
\text { Pedagang }\end{array}$ & $\begin{array}{c}\text { Jenis } \\
\text { Kelamin }\end{array}$ & Lokasi/tempat \\
\hline 1. & PNJ & Laki - laki & $\begin{array}{c}\text { Los daging lantai } 2 \\
\text { S. } 37\end{array}$ \\
\hline 2. & KRA & Laki - laki & $\begin{array}{c}\text { Los daging lantai } 1 \\
\text { Blok A }\end{array}$ \\
\hline 3. & ADI & Laki - laki & i Los dagin \\
\hline 4. & YMN & Peren & $\begin{array}{r}\text { Los dagin } \\
\text { Blo }\end{array}$ \\
\hline 5. & SRI & Pere & Los dagir \\
\hline 6. & SPT & Per & Los daging lantai 1 \\
\hline
\end{tabular}
berjumlah 6, maka semua sampel diambil dari masing-masing pedagang.

\section{B. Data Khusus}

Data khusus dari penelitian ini memberikan gambaran tentang prinsip hygiene sanitasi makanan meliputi bahan baku daging sapi, pemotongan daging sapi, penyajian daging sapi, personal hygiene penjamah daging sapi, perilaku penjamah daging sapi, sanitasi tempat penjualan daging sapi meliputi peralatan penjualan, tempat penjualan daging sapi dan kualitas mikrobiologi (Salmonella $s p$ ) pada daging sapi di Pasar Wage Kecamatan Purwokerto Timur Kabupaten Banyumas Tahun 2018 
1. Prinsip Hygiene Sanitasi Makanan

a. Bahan Baku Daging Sapi di Pasar Wage

Pengukuran penyediaan bahan baku daging sapi yang dijual dilakukan oleh peneliti dengan menggunakan lembar checklist. Jumlah pedagang yang dinilai bahan baku daging sapi sebanyak 6 sampel, dapat dilihat pada tabel berikut :

Tabel 2. Data Hasil Observasi Bahan Baku Daging Sapi di Pasar Wage

\begin{tabular}{ccccc}
\hline No. & Variabel & $\begin{array}{c}\text { Kode } \\
\text { Pedagang }\end{array}$ & Skor & Kategori \\
\hline 1. & & PNJ & 5 & MS \\
2. & Bahan & KRA & 5 & MS \\
3. & Baku & ADI & 5 & MS \\
4. & Daging & YMN & 5 & MS \\
5. & Sapi & SRI & 3 & TMS \\
6. & & SPT & 3 & TMS \\
\hline \multicolumn{2}{r}{ Berdasarkan } & hasil & penelitian ini
\end{tabular}
memberikan gambaran tentang keadaan hygiene sanitasi daging sapi yaitu bahan baku pada 6 pedagang daging sapi di Pasar Wage Kecamatan Purwokerto Timur Kabupaten Banyumas Tahun 2018. Cara pemilihan daging sapi segar menurut (Hadiwiyoto, 1983). Ciri-ciri daging sapi segar yaitu daging sapi mempunyai kenampakan mengkilat, warnanya merah segar dan tidak pucat, daging sapi tidak berbau asam apalagi busuk, daging sapi masih elastis dan tidak kaku, apabila dipegang daging sapi tidak lengket dan masih terasa kebasahannya.

Berdasarkan tabel 2 bahan baku dari 6 pedagang daging sapi tersebut yang memenuhi syarat 4 pedagang yaitu PNJ, KRA, ADI dan YMN mendapatkan skor 5 karena daging nampak mengkilat, warna merah segar dan tidak pucat, tidak tercium bau asam atau busuk, sifat elastik bila ditekan dengan jari akan segera kembali (kenyal) atau tidak kaku dan tidak lengket atau masih terasa kebasahannya. Sedangkan bahan baku daging sapi yang tidak memenuhi syarat 2 pedagang yaitu SRI dan SPT karena daging tidak nampak mengkilat, warna merah tidak segar atau pucat, lengket dan tidak terasa kebasahannya.

b. Pemotongan Daging Sapi di Pasar Wage

Pengukuran pemotongan daging sapi oleh peneliti dengan menggunakan lembar checklist. Jumlah pedagang yang dinilai pemotongan daging sapi sebanyak 6 sampel, dapat dilihat pada tabel berikut :

Tabel 3. Data Hasil Observasi Pemotongan Daging Sapi di Pasar Wage

\begin{tabular}{|c|c|c|c|c|}
\hline No. & Variabel & $\begin{array}{c}\text { Kode } \\
\text { Pedagang }\end{array}$ & Skor & Kat \\
\hline 1. & & PNJ & 2 & TMS \\
\hline 2. & & KRA & 2 & TMS \\
\hline 3. & Pemotongan & ADI & 2 & TMS \\
\hline 4. & Daging Sapi & YMN & 2 & TMS \\
\hline 5. & & SRI & 2 & TMS \\
\hline 6. & & SPT & 2 & TMS \\
\hline
\end{tabular}
memberikan gambaran tentang keadaan hygiene sanitasi daging sapi yaitu pemotongan daging sapi pada 6 pedagang daging sapi di Pasar Wage Kecamatan Purwokerto Timur Kabupaten Banyumas Tahun 2018. Menurut Keputusan Menteri Kesehatan Republik Indonesia Nomor 519/MENKES/SK/VI/2008 Tentang Pedoman Penyelenggaran Pasar Sehat mengenai tempat penjualan bahan pangan basah dan menurut (W.J. Corputty, 1977, h. 10) adalah pisau pemotong dalam keadaan baik (tidak berkarat), alas pemotong (talenan) tidak terbuat dari bahan kayu, tidak mengandung bahan beracun, kedap air, daging harus dipotong menurut serat dan ke satu arah.

Berdasarkan tabel 3 pemotongan daging dari 6 pedagang daging sapi tersebut tidak memenuhi syarat semua karena jumlah skor untuk memenuhi syarat pada variabel pemotongan daging sapi yaitu 3. Komponen yang belum memenuhi syarat yaitu alas pemotongan (talenan) terbuat dari bahan kayu.

c. Penyajian Daging Sapi di Pasar Wage

Pengukuran penyajian daging sapi oleh peneliti dengan menggunakan lembar checklist. Jumlah pedagang yang dinilai penyajian daging sapi sebanyak 6 sampel, dapat dilihat pada tabel berikut :

Tabel 4. Data Hasil Observasi Penyajian Daging Sapi di Pasar Wage

\begin{tabular}{ccccc}
\hline No. & Variabel & $\begin{array}{c}\text { Kode } \\
\text { Pedagang }\end{array}$ & Skor & Kategori \\
\hline 1. & & PNJ & 0 & TMS \\
2. & Penyajian & KRA & 0 & TMS \\
3. & Daging & YDI & 0 & TMS \\
4. & Sapi & YMN & 1 & TMS \\
5. & & SRI & 1 & TMS \\
6. & & SPT & 0 & TMS \\
\hline
\end{tabular}


Berdasarkan hasil penelitian ini memberikan gambaran tentang keadaan hygiene sanitasi daging sapi yaitu penyajian daging sapi pada 6 pedagang daging sapi di Pasar Wage Kecamatan Purwokerto Timur Kabupaten Banyumas Tahun 2018. Persyaratan penyajian makanan menurut Keputusan Menteri Kesehatan RI No. 942/MENKES/SK/VII Tahun 2003 Tentang Pedoman Persyaratan Hygiene Sanitasi Makanan Jajanan, daging sapi disajikan dengan tempat penyajian bersih, penyajian daging sapi tertutup dan penutup dalam keadaan bersih.

Berdasarkan tabel 4 penyajian daging dari 6 pedagang daging sapi tersebut tidak memenuhi syarat semua karena jumlah skor untuk memenuhi syarat pada variabel penyajian daging sapi yaitu 3 . Komponen yang belum memenuhi syarat yaitu penyajian daging sapi tidak tertutup, tidak ada penutup dalam keadaan bersih dan tempat penyajian tidak bersih.

\section{d. Personal Hygiene}

Pengukuran personal hygiene penjamah daging sapi dilakukan oleh peneliti dengan menggunakan lembar checklist. Jumlah pedagang yang dinilai personal hygienenya yaitu sebanyak 6 sampel, dapat dilihat pada tabel berikut :

Tabel 5. Data Hasil Observasi Personal

Hygiene Pedagang Daging Sapi di Pasar Wage

\begin{tabular}{ccccc}
\hline No. Variabel & $\begin{array}{c}\text { Kode } \\
\text { Pedagang }\end{array}$ & Skor & Kategori \\
\hline 1. & & PNJ & 7 & TMS \\
2. & & KRA & 7 & TMS \\
3. Personal & ADI & 7 & TMS \\
4. Hygiene & YMN & 6 & TMS \\
5. & & SRI & 6 & TMS \\
6. & SPT & 6 & TMS \\
\hline \multicolumn{2}{c}{ Berdasarkan } & hasil & penelitian ini
\end{tabular}
memberikan gambaran tentang keadaan penjamah daging sapi yaitu personal hygiene pada 6 pedagang daging sapi di Pasar Wage Kecamatan Purwokerto Timur Kabupaten Banyumas Tahun 2018. Menurut Keputusan Menteri Kesehatan RI No. 942/MENKES/SK/VII/2003 Tentang Persyaratan Higiene Sanitasi Makanan Jajanan, personal hygiene yang baik yaitu meliputi penjamah tidak menderita penyakit mudah menular (batuk, pilek, influenza, diare), tangan dalam keadaan bersih, rambut dalam keadaan rapi, kuku dalam keadaan bersih, pakaian bersih dan rapi, memakai celemek, mencuci tangan setiap akan menangani makanan, memakai alat atau alas tangan (sarung tangan) dan menutup luka.

Berdasarkan tabel 5 personal hygiene dari 6 pedagang daging sapi tersebut tidak memenuhi syarat semua karena jumlah skor untuk memenuhi syarat pada variabel personal hygiene yaitu 9. Komponen yang belum memenuhi syarat yaitu tidak memakai celemek, tidak mencuci tangan setiap akan menangani makanan dan tidak memakai sarung tangan.

\section{e. Perilaku Penjamah}

Pengukuran perilaku penjamah daging sapi dilakukan oleh peneliti dengan menggunakan lembar checklist. Jumlah pedagang yang dinilai perilaku penjamah yaitu sebanyak 6 sampel, dapat dilihat pada tabel berikut :

Tabel 6. Data Hasil Observasi Perilaku Penjamah Daging Sapi di Pasar Wage

\begin{tabular}{lcccc}
\hline No. & Variabel & $\begin{array}{c}\text { Kode } \\
\text { Pedagang }\end{array}$ & Skor Kategori \\
\hline 1. & & PNJ & 3 & MS \\
2. & & KRA & 3 & MS \\
3. Perilaku & ADI & 3 & MS \\
4. & Penjamah & YMN & 3 & MS \\
5. & SRI & 3 & MS \\
6. & SPT & 3 & MS \\
\hline \multicolumn{2}{c}{ Berdasarkan } & hasil & penelitian ini
\end{tabular}
memberikan gambaran tentang keadaan penjamah daging sapi yaitu perilaku penjamah pada 6 pedagang daging sapi di Pasar Wage Kecamatan Purwokerto Timur Kabupaten Banyumas Tahun 2018. Menurut Keputusan Menteri Kesehatan RI No. 942/MENKES/SK/VII/2003 Tentang Persyaratan Higiene Sanitasi Makanan Jajanan, perilaku penjamah yang baik yaitu meliputi tidak sambil merokok, tidak sambil menggaruk anggota badan dan tidak batuk atau bersin dihadapan makanan atau bahan baku makanan.

Berdasarkan tabel 6 perilaku penjamah dari 6 pedagang daging sapi tersebut memenuhi syarat semua karena jumlah skor pada variabel perilaku penjamah setiap pedagang telah memenuhi syarat yaitu 3. Komponen perilaku penjamah yaitu tidak sambal 
merokok, tidak sambil menggaruk anggota badan, tidak batuk dan bersin dihadapan bahan baku daging sapi.

\section{Sanitasi Tempat Penjualan}

\section{a. Peralatan Penjualan}

Pengukuran kualitas kebersihan peralatan penjualan yang digunakan oleh pedagang daging sapi dilakukan oleh peneliti dengan menggunakan lembar checklist. Jumlah pedagang yang dinilai kebersihan peralatannya sebanyak 6 sampel, dapat dilihat dari tabel berikut ini

Tabel 7. Data Hasil Observasi Peralatan Penjualan Daging Sapi di Pasar Wage

\begin{tabular}{llccc}
\hline No. & Variabel & $\begin{array}{c}\text { Kode } \\
\text { Pedagang }\end{array}$ & Skor Kategori \\
\hline 1. & & PNJ & 4 & MS \\
2. & KRA & 4 & MS \\
3. & Peralatan & ADI & 4 & MS \\
4. & Penjualan & YMN & 4 & MS \\
5. & & SRI & 4 & MS \\
6. & SPT & 4 & MS \\
\hline \multicolumn{2}{r}{ Berdasarkan } & hasil & penelitian ini
\end{tabular}
memberikan gambaran tentang keadaan sanitasi tempat penjualan daging sapi yaitu peralatan penjualan pada 6 pedagang daging sapi di Pasar Wage Kecamatan Purwokerto Timur Kabupaten Banyumas Tahun 2018. Persyaratan peralatan penjualan untuk penjualan daging sapi menurut Reksosoebroto (1978, h. 115): tidak berkarat, mudah dibersihkan, tidak terbuat bahan-bahan yang mengandung racun (tembaga, seng atau cadmium), peralatan dibersihkan sebelum dan setelah digunakan.

Berdasarkan tabel 7 peralatan penjualan dari 6 pedagang daging sapi tersebut memenuhi syarat semua karena jumlah skor pada variabel peralatan setiap pedagang telah memenuhi syarat yaitu 4 . Komponen peralatan penjualan yaitu tidak berkarat, mudah dibersihkan, tidak terbuat bahan-bahan yang mengandung racun, dibersihkan sebelum dan setelah digunakan.

\section{b. Tempat Penjualan}

Pengukuran kondisi tempat penjualan daging sapi yang dilakukan oleh peneliti dengan menggunakan lembar checklist. Jumlah pedagang yang dinilai tempat penjualannya sebanyak 6 sampel, dapat dilihat pada tabel :

Tabel 8. Data Hasil Observasi Tempat Penjualan Daging Sapi di Pasar Wage

\begin{tabular}{ccccc}
\hline No. & Variabel & $\begin{array}{c}\text { Kode } \\
\text { Pedagang }\end{array}$ & Skor & Kategori \\
\hline 1. & & PNJ & 2 & TMS \\
2. & & KRA & 5 & TMS \\
3. & Tempat & ADI & 2 & TMS \\
4. & Penjualan & YMN & 2 & TMS \\
5. & & SRI & 1 & TMS \\
6. & & SPT & 1 & TMS \\
\hline \multicolumn{2}{r}{ Berdasarkan } & hasil & penelitian ini
\end{tabular}

memberikan gambaran tentang keadaan tempat penjualan daging sapi pada 6 pedagang daging sapi di Pasar Wage Kecamatan Purwokerto Timur Kabupaten Banyumas Tahun 2018. Menurut Keputusan Menteri Kesehatan Republik Indonesia Nomor 519/MENKES/SK/VI/ 2008 Tentang Pedoman Penyelenggaran Pasar Sehat mengenai tempat penjualan bahan pangan basah, yaitu meliputi penyajian daging harus digantung, tersedia tempat untuk pencucian bahan pangan dan peralatan, tersedia tempat cuci tangan yang dilengkapi dengan sabun dan air yang mengalir, saluran pembuangan limbah tertutup, tersedia tempat sampah kering dan basah, dan tempat penjualan bebas vektor penularan penyakit seperti: lalat, kecoa dan tikus.

Berdasarkan tabel 8 tempat penjualan dari 6 pedagang daging sapi tersebut tidak memenuhi syarat semua karena jumlah skor untuk memenuhi syarat pada variabel tempat penjualan yaitu 6 . Komponen yang belum memenuhi syarat yaitu tidak tersedia tempat untuk pencucian bahan pangan dan peralatan, tidak tersedia tempat cuci tangan dengan sabun dan air mengalir, tidak ada saluran pembuangan limbah tertutup, tidak tersedia tempat sampah kering dan basah, tempat penjualan tidak bebas dari vektor penularan penyakit.

3. Pemeriksaan Kualitas Mikrobiologi (Salmonella sp) Pada Daging Sapi

Pemeriksaan sampel kualitas mikrobiologi (Salmonella $s p$ ) pada daging sapi dilakukan di Laboratorium Poltekkes Kemenkes Semarang Kampus 7 Jurusan Kesehatan Lingkungan Purwokerto. Jumlah daging sapi yang diperiksa yaitu 6 sampel, diperoleh hasil seperti tabel berikut :

Tabel 9. Kualitas Mikrobiologi (Salmonella sp) Pada Daging Sapi di Pasar Wage

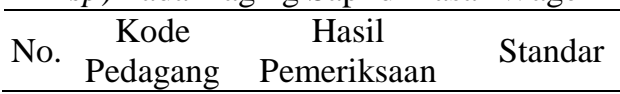




\begin{tabular}{lccc}
\hline \multicolumn{3}{c}{ Salmonella $s p$} & \\
\hline 1. & PNJ & Negatif & \\
2. & KRA & Negatif & \\
3. & ADI & Negatif & Negatif/25 \\
4. & YMN & Negatif & gram \\
5. & SRI & Positif & \\
6. & SPT & Positif & \\
\hline
\end{tabular}

Peraturan Badan Pengawas Obat dan Makanan Republik Indonesia Nomor HK.00.06.1.52.4011 tentang Penetapan Batas Maksimum Cemaran Mikroba dan Kimia dalam Makanan, bakteri Salmonella sp pada daging sapi atau olahan adalah negatif/25 gram.

Berdasarkan tabel 9 kualitas mikrobiologi (Salmonella $s p$ ) dari 6 pedagang daging sapi tersebut 4 sampel memenuhi syarat dan 2 sampel tidak memenuhi syarat (positif Salmonella sp).

\section{Kesimpulan dan Saran \\ Kesimpulan}

1. Prinsip hygiene sanitasi makanan mengenai bahan baku daging sapi diperoleh hasil dengan kategori 4 sampel memenuhi syarat dan 2 sampel tidak memenuhi syarat, pada pemotongan daging sapi, penyajian daging sapi, personal hygiene diperoleh hasil dengan kategori tidak memenuhi syarat dan perilaku penjamah diperoleh hasil dengan kategori memenuhi syarat.

2. Sanitasi tempat penjualan meliputi peralatan penjualan diperoleh hasil dengan kategori memenuhi syarat dan tempat penjualan diperoleh hasil dengan kategori tidak memenuhi syarat.

3. Hasil pemeriksaan laboratorium pada sampel daging sapi dari 6 pedagang diperoleh hasil dengan kategori 4 pedagang negatif bakteri Salmonella sp (tidak ada Salmonella) dan 2 pedagang positif bakteri Salmonella $s p$.

Saran

1. Diharapkan kepada masyarakat tetap waspada terhadap pemilihan bahan baku makanan yang baik dikonsumsi.

2. Diharapkan pedagang mengikuti penyuluhan mengenai hygiene sanitasi daging sapi, personal hygiene dan sanitasi tempat penjualan setiap ada penyuluhan dari dinas kesehatan setempat.

3. Diharapkan pedagang alas pemotong (talenan) menggantinya dengan bahan plastik polypropylene anti pencemaran bakteri.

4. Diharapkan pedagang menjaga kebersihan tempat penyajian dan menyediakan penutup yang bersih pada penyajian daging sapi.

5. Diharapkan pedagang mencuci tangan setiap akan menangani makanan dan menyediakan sarung tangan yang bersih dengan menggunakan sarung tangan plastik untuk sekali pakai.

6. Menyediakan galon air minum yang berisi air bersih disertai sabun cair untuk mencuci peralatan dan tempat cuci tangan.
7. Menyediakan tempat sampah kering dan basah dengan ember tertutup untuk tempat sampah sementara.

8. Melakukan kegiatan pengendalian vektor dengan meletakkan dedaunan yang beraroma seperti kemangi dan lavender untuk pengendalian lalat, memberi bahan kimia (blattanex gel) secukupnya pada setiap sudut tempat penjualan untuk pengendalian kecoa dan memasang lem tikus untuk pengendalan tikus.

9. Diharapkan pihak pasar menyediakan sanitasi tempat penjualan daging sapi yang memenuhi syarat.

10. Bagi Dinas Kesehatan Kabupaten Banyumas, diharapkan dapat melakukan pemantauan kepada pedagang dan memberikan penyuluhan minimal 3x dalam satu bulan mengenai hygiene sanitasi daging sapi, personal hygiene dan sanitasi tempat penjualan kepada pedagang daging sapi.

11. Bagi petugas sanitasi puskesmas diharapkan dapat melakukan pengawasan hygiene sanitasi tempat penjualan di wilayah kerjanya minimal $1 \mathrm{x}$ dalam 2 minggu.

\section{Daftar Pustaka}

Arisman. 2009. Keracunan Makanan. Buku Ajar Ilmu Gizi. Jakarta: EGC

Asep Tata Gunawan. 2017. Modul Praktikum Penyehatan Makanan \& Minuman A. Jakarta: Hipokrates

Aziz Alimul Hidayat. 2010. Metode Penelitian Kebidanan \& Teknik Analisis Data. Jakarta: Salemba Medika

Badan Pengawas Obat dan Makanan RI.2009. Penetapan Batas Maksimum Cemaran Mikroba dan Kimia dalam Makanan Nomor HK.00.06.1.52.4011. Jakarta: BPOM RI

Bening Ratri Wiji. 2016. Studi Hygiene Sanitasi Pengolahan Makanan dan Kandungan Salmonella sp Pada Bakso Yang Dijual di JL. Jenderal Sudirman Sokaraja Tahun 2016. Karya Tulis Ilmiah. Purwokerto: Kementerian Kesehatan RI Politeknik Kesehatan Semarang Jurusan Kesehatan Lingkungan Purwokerto

Depkes RI. 1997. Bakteri Pencemar Makanan dan Penyakit Bawaan Makanan. Jakarta: Depkes RI

Depkes RI. 1998. Pedoman Pengawasan Kualitas Makanan. Jakarta: Ditjen PPM dan PLP Depkes RI 
Depkes RI. 2004. Hygiene Sanitasi Makanan dan Minuman. Jakarta: Dirjen PPM dan PL

Depkes RI. 2009. Rencana Pembangunan Jangka Panjang Bidang Kesehatan 2005-2025. Jakarta: Depkes RI

Direktorat Jenderal PP \& PL KEMENTERIAN KESEHATAN RI. 2010. Kumpulan Modul Kursus Hygiene Sanitasi Makanan \& Minuman. Jakarta: Depkes RI

Emil Salim. 2013. Sukses Bisnis dan Beternak Sapi Potong. Yogyakarta: Andi

Hadiwiyoto. 1983. Hasil-hasil Olahan Susu, Ikan, Daging, dan Telur. Yogyakarta: Liberty

http://kaltim.tribunnews.com/2017/05/12/70-orangyang-keracunan-diduga-karena-santaprendang -daging-sapi-asal-malaysia. (5 Juni 2018 pukul 05.30 WIB)

KEPMENKES RI No.942/MENKES/SK/VII/2003 tentang Persyaratan Higiene Sanitasi Makanan Jajanan

KEPMENKES RI No. 519/MENKES/SK/VI/2008 tentang Pedoman Penyelenggaraan Pasar Sehat

Leni Herliani Afrianti. 2010. Pengawet Makanan Alami Dan Sintetis. Bandung: Alfabeta

Lukman Saksono. 1986. Pengantar Sanitasi Makanan. Bandung: Alumni

Muhammad Nurhadi. 2012. Kesehatan Masyarakat Veteriner. Yogyakarta: Gosyen Veteriner. Yogyakarta: Gosyen

M. J Pelzcar dan E.C.S Chan. 1988. Dasar-Dasar Mikrobiologi. Jakarta: Universitas Indonesia

M. Juni Mirzal Al furqon. 2012. Makanan dan Salmonella sp. Jakarta: Transmedia Pustaka

Nurul Amaliyah. 2017. Penyehatan Makanan Dan Minuman - A. Yogyakarta: Deepublish

Permenkes RI No.1096/Menkes/Per/VI/2011 tentang Hygiene Sanitasi Jasaboga

Reksosoebroto.1978. Ilmu Hygiene Sanitasi, Jilid I, II. Jakarta: Depkes

Retno Widyati, dkk. 2002. Hygiene \& Sanitasi Umum dan Perhotelan. Jakarta: Grasindo

Soeparno. 2009. Ilmu dan Teknologi Daging. Yogyakarta: Gadjah Mada University Press
Standar Nasional Indonesia 7388:2009 tentang Batas Maksimum Cemaran Mikroba dalam Pangan, Jakarta

Suparlan. 2012. Pengantar Pengawasan Hygiene Sanitasi Tempat-Tempat Umum Wisata \& Usaha-Usaha Untuk Umum. Surabaya: Percetakan Duatujuh

Tri Cahyono. 2018. Panduan Penulisan Tugas Akhir. Purwokerto: Kementerian Kesehatan RI Politeknik Kesehatan Semarang Jurusan Kesehatan Lingkungan Purwokerto

WHO. 2002. Buku Penyakit Bawaan Makanan Fokus Pendidikan Kesehatan. Jakarta: Buku Kedokteran EGC

W. J. Corputty. 1977. Pengetahuan Barang Makanan cetakan kedua. Jakarta: Balai Pustaka

Yusta Akhnisia. 2008. Studi Kandungan Bakteri Salmonella sp pada Daging Sapi Segar Yang Dijual di Pasar Kecamatan Kutoarjo Kabupaten Purworejo Tahun 2008. Karya Tulis Ilmiah. Purwokerto: Kementerian Kesehatan RI Politeknik Kesehatan Semarang Jurusan Kesehatan Lingkungan Purwokerto 